\title{
Altitudinal diversity of tribe Bombini (Hymenoptera: Apidae) from district Shigar, Gilgit Baltistan
}

\author{
Sakhawat Ali ${ }^{1 *}$, Sajid Ali Shah ${ }^{1}$, Imran Khatri ${ }^{1}$, Asad Rajput ${ }^{1}$, Ghulam \\ Qadeer Junejo ${ }^{1}$ and Riaz Hussain ${ }^{2}$ \\ 1. Department of Entomology, Sindh Agriculture University Tandojam-Pakistan \\ 2. Department of Entomology, PMAS Arid Agriculture University, Rawalpindi-Pakistan \\ *Corresponding author's email: sakhifida512@gmail.com
}

Citation

Sakhawat Ali, Sajid Ali Shah, Imran Khatri, Asad Rajput, Ghulam Qadeer Junejo and Riaz Hussain. Altitudinal diversity of tribe Bombini (Hymenoptera: Apidae) from district Shigar, Gilgit Baltistan. Pure and Applied Biology. Vol. 10, Issue 3, pp651-656. http://dx.doi.org/10.19045/bspab.2021.100067

\begin{tabular}{llll}
\hline \hline Received: 30/11/2019 & Revised: 20/10/2020 & Accepted: 29/10/2020 & Online First: 24/11/2020 \\
\hline \hline
\end{tabular}

\section{Abstract}

Bumble bees plays an important role in pollination of crops and environmental indicators. Identification of bumble bees are also important as different species plays various role in ecosystem. Present study was conducted to know the altitudinal diversity of tribe Bombini. Samples were collected from various localities of district Shigar of Baltistan Division. Identification were done at Insect Systematic Laboratory of Entomology department, Sindh Agriculture University Tandojam. During present study 7 species are recorded under single genus Bombus, from the collection sites viz, B. asiaticus (Morawitz, 1875), B. melanurus (Lepeletier, 1835), B. semenovianus (Skorikov, 1914), B. tunicatus (Smith, 1852), B. ferganicus (Radoszkowski, 1893), B. lucorum (Linnaeus, 1761) and B. rufofasciatus (Smith, 1852). The list of host plants are recorded as, Euphorbia wallichia, Cirsium arvense, Carduus edelbergii, Lavatera cashmeriana, Cirsium arvense, Melilotus officinale, Taraxacum officinale, Ipomea tricolor, Helianthus annuus, Digitalis purpurea, Zinnia elegans and Fagopyrum esculentum. This study will proved helpful to recognize the bumble species as pollinator of different crops of the region for conservation.

Keywords: Bombini; Bumble bees; Bombus; Pollinators; Shigar

\section{Introduction}

The Bombini are a tribe of large bristly apid bees which contain a single living genus, Bombus, the bumblebees, and some extinct genera such as Calyptapis and Oligobombus. The tribe was described by Latreille in 1802. The genus Bombus, includes around 260 species of eusocial bees, mostly distributed in temperate and cold regions of the northern hemisphere [1]. Agricultural crops vary in their pollination requirements and rely on different insect pollinator species $[2,3]$. Bumblebees play an important role as pollinator in functioning of agricultural ecosystems of crops and wild flowers. Plant pollinated by Bees contribute $30 \%$ of food consumption by human in America. [4]. Thirteen species reported in Pakistan [13] all of them are indigenous to northern Pakistan, having the elevation ranges from $2291 \mathrm{~m}$ to $5344 \mathrm{~m}$ both from agricultural and non-agricultural land [5]. Species of tribe Bombini can feed in hostile weather conditions, which are not suitable to honeybees and solitary bees [6]. These perform an important role in ecological services in high altitude areas of Pakistan [7]. From Himalayan region 160 
floral host plants has been recorded [8]. Tribe Bombini are mostly found in high attitude regions [12]. Species of tribe Bombini can found from $1000 \mathrm{~m}-5500 \mathrm{~m}$. Bumble bees construct nest in different habitat, often in abandoned rodent burrows, in the ground, above ground and in tall grasses [9]. Shigar district is located in the north of Skardu. It is part of the central Karakorum ranges. It lies at $25^{\circ} 25^{\prime} 32^{\prime \prime} \mathrm{N}$ latitude and $75^{\circ} 42^{\prime} 59^{\prime \prime} \mathrm{E}$ longitude and covers an area of 4373 sq. km. Elevation above sea level is 2, 260 to $8611 \mathrm{~m}$ (Fig. 1) [10]. It borders with China surrounded by K2 between the territories [11]. Present study was conducted to explore the bumble bee fauna as pollinator, since identification plays a vital role towards the knowledge of pollinating species behavior and their extent of benefits.

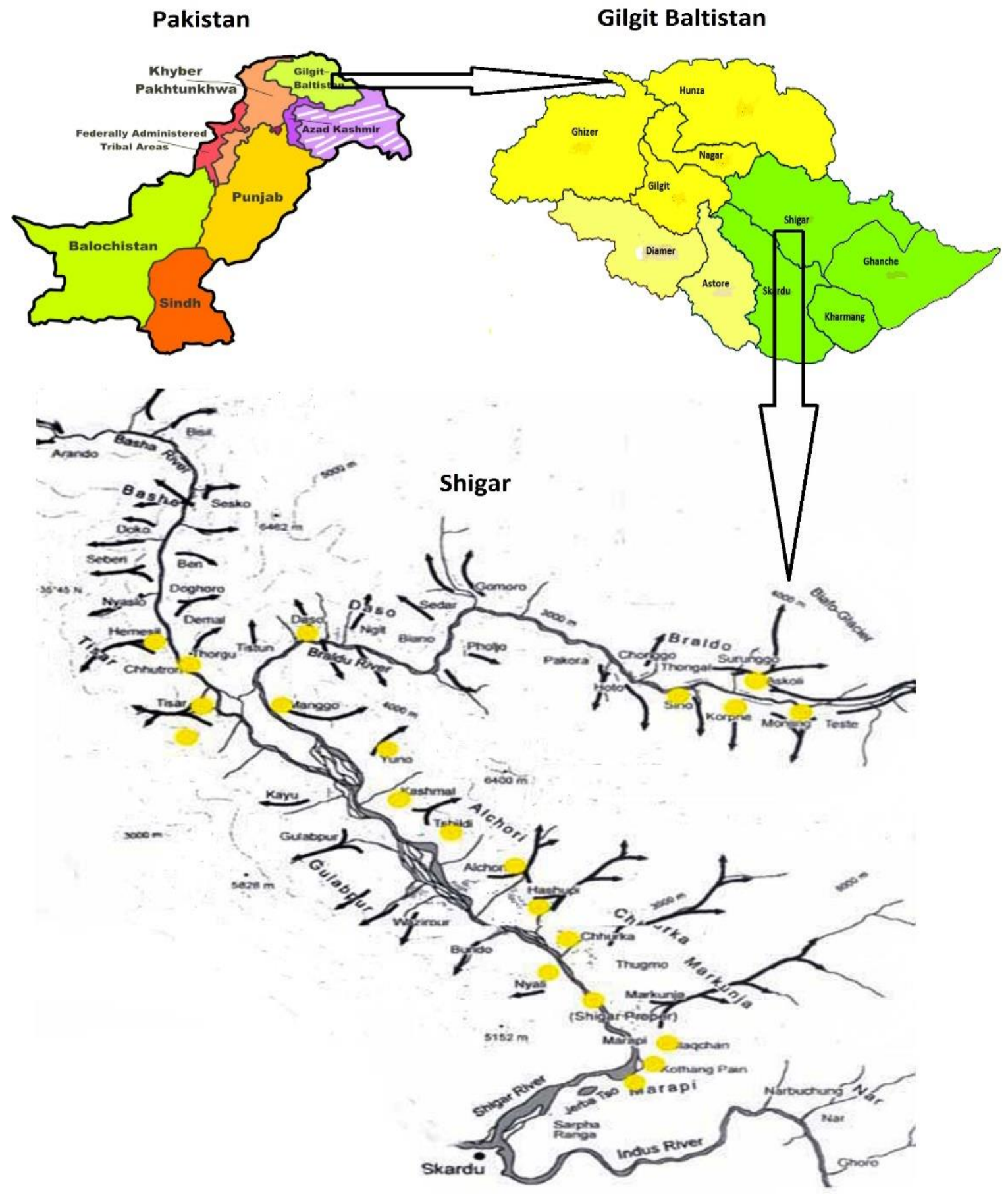

Figure 1. Map of study area 


\section{Materials and Methods}

For present research, bumble bees were collected through sweep net from various localities of district Shigar, Gilgit Baltistan. Specimens were killed by using potassium cyanide and pinned by standard entomological pins. After pining, they were labeled with information of locality, collection date, collector name, and the host tree. Identification were done at Insect Systematic Laboratory, Department of Entomology, Sindh Agriculture University Tandojam by [15] colour pattern key of [16].

Images of habitus (adult) were taken by using high pixel camera, and $350 \mathrm{k}$ pixel, USB camera fitted on microscopes Labomed CSM2 (20X and 40X), used for genetalia images.

\section{Results}

\section{Bombus asiaticus Morawitz, 1875 \\ Diagnosis}

Body densely robust with pubescence, head with black pubescence; antennae elbow shape, thorax with white pubescence and black in middle; forewings light brown and transparent hindwings, abdomen with sparse orange setae, densely black in middle and proximal end of abdomen yellowish orange pubescence [15].

\section{Material examined}

Pakistan: 23ㅇ, Gilgit Baltistan Prov., Alchori, Askoli, Kashmal, Kurfy, Monjong, Sildi, Sinu, Thadoro, Tissar, Yono, 24.Vii.2019, S.Ali,

\section{Host plants}

Wild Flower, Ipomea tricolor, Lavatera cashmeriana and Zinnia elegans.

\section{Bombus ferganicus Radoszkowski,} 1893

\section{Diagnosis}

Head and thorax with yellow ochraceous pubescence, tarsi yellow coloured, and abdomen black dorsally, last segments yellow ochraceous laterally. Hindwings brownish

\section{Material examined}

Pakistan: 8ㅇ, Gilgit Baltistan Prov., Askoli, Kurfy, Monjong 12.Viii.2019, S.Ali,

\section{Host plants}

Euphorbia wallichia, Cirsium arvense, Carduus edelbergii and Lavatera cashmeriana

\section{Bombus lucorum (Linnaeus, 1761)}

\section{Diagnosis}

Head black, thorax proximal portion yellow and mid with black pubescens. Upper $1 / 3$ of abdomen yellow ochraceous, blackish in the middle and with white pubescence at the posterior end of abdomen. Hind and forewings light brown and transparent.

\section{Material examined}

Pakistan: 20, Gilgit Baltistan Prov., Chutron, Haiderabad, Molto, Tissar, 24.Viii.2019, S.Ali,

\section{Host plants}

Melilotus officinale, Taraxacum officinale, Ipomea tricolor, Helianthus annuus, Digitalis purpurea. Euphorbia wallichia, Cirsium arvense, Carduus edelbergii, Lavatera cashmeriana and Zinnia elegans

4. Bombus melanurus Lepeletier, 1835

\section{Diagnosis}

Head black, thorax completely yellowish, half of the abdomen yellow with blackish brown markings in center, half of the abdomen posteriorly black. Forewing and hindwings light brown.

\section{Material examined}

Pakistan: 20, Gilgit Baltistan Prov., Chutron, Haiderabad, Molto, Tissar 24. Viii. 2019, S.Ali,

\section{Host plants}

Wild Flower Melilotus officinale and Taraxacum officinale.

\section{Bombus rufofasciatus Smith, 1852 Diagnosis}

Head pubescence black, thorax with row of white long setae at the anterior margin, rest of the thorax complete black. Half of the abdomen black, posterior half of the abdomen with row of white setae, yellow and some orange setae present posteriorly. Legs with long dense setae. Forewing and hindwing light brown and transparent.

\section{Material examined}

Pakistan: 8ㅇ, Gilgit Baltistan Prov., Askoli, Kurfy, Monjong, 12.Viii.2019, S.Ali, 
Host plants

Fagopyrum esculentum, Euphorbia wallichia, Carduus edelbergii and Taraxacum officinale.

6. Bombus semenovianus (Skorikov, 1914)

\section{Diagnosis}

Head black, thorax with yellow dense pubescence, $2 / 3$ of the abdomen at the anteriorly blackish, whereas, $1 / 3$ of posterior portion of abdomen orange.

Material examined

Pakistan: 16우, Gilgit Baltistan Prov., Askoli, Kurfy, Monjong, Sinu Tissar. 11. Viii. 2019, S.Ali,

\section{Host plants}

Fagopyrum esculentum, Wild Flower. Euphorbia wallichia, Cirsium arvense and Digitalis purpurea

\section{Bombus tunicatus Smith, 1852}

\section{Diagnosis}

Head with white pubescence, thorax with black pubescence proximally, distally with white setae. Major portion of the abdomen covered with black setae, posterior part of the abdomen orange.

\section{Material examined}

Pakistan, 30, Gilgit Baltistan Prov., Alchori, Askoli, Braqchan, Churka, Chutron, Haiderabad, Hashupi, Kashmal, Kurfy, Monjong, Sildi, Sinu, Tissar,. 11. Viii.2019, S.Ali,

\section{Host plants}

Fagopyrum esculentum, Wild Flower. Euphorbia wallichia, Cirsium arvense and Digitalis purpurea

Elevation wise distribution of Bumble bees in Shigar district

Five species were collected at the height of 9000 to $10000 \mathrm{ft}$ include; Bombus semenovianus, Bombus rufofasciatus, Bombus asiaticus, Bombus melanurus, Bombus ferganicus; and four species from 8000 to 9000; Bombus semenovianus, Bombus lucorum, Bombus asiaticus, Bombus tunicatus; lastly, three species were recorded at the low altitude of 7000 8000; Bombus tunicatus, Bombus asiaticus, Bombus lucorum.

\section{Discussion}

The present study area was ranged at the altitude of 7000-10000 feet, the climate at various height also varies, and the vegetation is also varies at different altitudes. During present study 7 species of tribe Bombini were recorded from different locations of district Shigar. Collection were done in different timings from $8 \mathrm{am}$ to $5 \mathrm{pm}$. Most of them were active after $12 \mathrm{pm}$. B. rufofasciatus forages heavily in the afternoon, with restricted activity in the early morning and late in the evening at high altitudes [17]. All species are previously reported from different localities of Gilgit Baltistan. Previously the bumble bee fauna of present study area was not extensively studied. This study carried out to explore the bumble bee fauna of district Shigar. [18] Reported 9 species from Hashupi, Shigar. Bombus branickii new addition in bumble bee fauna of Pakistan was reported from Kharmang, Gilgit Baltistan [19]. Previously 13 species of bumble bee was recorded by [13] from Gilgit Baltistan. [14] Reported Bombus rufofasciatus, $\quad B . \quad$ subtypicus, $B$. kashmirensis, $B$. trifasciatus, and $B$. haemorrhoidalis first time from Naran Kaghan valley, Pakistan. Species recorded during present study were collected from high elevations. Previously reported bumble bees of Pakistan was recorded from high altitude regions like Gilgit Baltistan, Azad Kashmir and Swat Pakistan. Three species of bumble bees namely Bombus rufofasciatus, Bombus asciaticus and Bombus haemorrhoidalis from swat. [20]. The study will proved helpful to identify the bumble bee as pollinator and conservation in respective region.

\section{Conclusion}

Present study revealed the occurrence of 7 species of bumble bees in surroundings of district Shigar, Gilgit Baltistan. They prefer higher elevation and the raining seasons effect their active time, especially for collections. 


\section{Authors' contributions}

Conceived and designed the experiments: $S$ Ali \& I Khatri, Performed the experiments: S Ali \& SA Shah, Analyzed the data: S Ali \& I Khatri, Contributed materials/ analysis/ tools: A Rajput, GQ Junejo \& R Hussain, Wrote the paper:S Ali \& I Khatri.

\section{References}

1. Williams PH (2018). In a group of its own? Rediscovery of one of the world's rarest and highest mountain bumblebees, Bombus tanguticus. J Nat Hist 52(5-6): 305-321.

2. Morse RA \& Calderone NW (2000). The value of honey bees as pollinators of US. Bee culture 128(3): 1-15.

3. Garibaldi LA, Dewenter SI, Winfree R, Aizen MA, Bommarco R, Cunningham SA, Kremen C, Carvalheiro LG, Harder LD, Afik O, Bartomeus I, Benjamin F \& Boreux V (2013). Wild pollinators enhance fruit set of crops regardless of honey bee abundance. Sci 339: 1608-1611.

4. Heinrich B (1979). Resource heterogeneity and patterns of movement in foraging bumblebees. Oecologia 40: 235-245.

5. Sheikh UAA, Ahmad M, Aziz MA, Naeem M, Bodlah I, Imran M \& Nasir M (2015). First record of Genus Bombus Latreille (Hymenoptera: Apidae, Bombini) in Naran Kaghan valley of Pakistan and their floral host range. J Biol \& Environ Sci 7(1): 215223.

6. Wardell GA, Bernhardt P, Bitner R, Burquez A, Buchmann S, Cane J, Cox AP, Dalton AP, Feinsinger P, Ingram M, Inouye D \& Jones CE (1998). The potential consequences of pollinator declines on the conservation of biodiversity and stability of food crop yields. Conserv Biol 12: 8-17.

7. Sabir AM, Suhail A, Rafi MA, Mahmood K \& Ahmed S (2007). Foraging activity of bumblebees (Bombus Latr.) in relation to floral resources in agricultural and semi- natural landscape. International Conference on Biological Resources of Pakistan: Problems, success and future perspectives at University of Arid Agriculture, Rawalpindi., Pakistan. pp 25.

8. Raina RH (2011). Species diversity and role of some dominant bumblebee species in the pollination ecology of Kashmir Himalaya. PhD. Thesis. pp 124.

9. Kearns CA \& Thomson JD (2001). The natural history of bumblebees: a source book for investigation, first edition. Boulder: University Press of Colorado. Kevan, PG 1976. Fluorescent nectar (technical comment). Sci 194: 341342.

10. Schmidt M (2000). Pastoral systems in Shigar/Baltistan: communal herding management and pasturage rights. High mountain pastoralism in Northern Pakistan 132: 121.

11. Seong YB, Bishop MP, Bush A, Clendon P, Copland L \& Finkel RC (2009). Landforms and landscape evolution in the Skardu, Shigar and Braldu valleys, central Karakoram. Geomorphol 103(2): 251-267.

12. Saini MS, Raina RH \& Khan ZH (2012). Food plants and stratification of bumblebees (Apidae: Hymenoptera) from Indian Himalayas. Ann Entomol Soc Am 30: 81-89.

13. Suhail A, Sabir AM, Asghar M, Rafi MA \& Qadir A (2009). Geographic distributional patterns of the genus Bombus (Bombini, Apidae: Hymenoptera) in northern Pakistan. Biol Dis Con 2: 1-9.

14. Sheikh UAA, Ahmad M, Imran M, Nasir M, Saeed S \& Bodlah I (2014). Distribution of Bumblebee, Bombus haemorrhoidalis Smith, and its Association with Flora in Lower Northern Pakistan. Pak J Zool 46(4): 1045-1051.

15. Williams PH (1991). The bumble bees of the Kashmir Himalaya 
(Hymenoptera: Apidae: Bombini). Bull Br Mus Nat Hist Entomol Ser 1204.

16. Williams $\mathrm{PH}$, Ito $\mathrm{M}$, Matsumura $\mathrm{T} \&$ Kudo I (2010). The bumblebees of the Nepal Himalaya (Hymenoptera: Apidae). Insecta Matsumurana 66: 115-151.

17. Saini. MS, Raina RH and Khan ZH, (2012). Taxonomy and pollination ecology of Bombus rufofasciatus (Hymenoptera: Apidae) from the Indian Himalaya. Pol J Entomol 81(4): 347-363.

18. Jaffar S, Shah F, Ali S, Yaseen M, Rizvi SAH \& Hassan MA (2019).
Taxonomy and distribution of bumblebees (Hymenoptera: Apidae) of district Skardu, Gilgit Baltistan. $J$ Entomol Zool Stud 7(1): 83-89.

19. Sheikh UAA, Mahmood K, Nazir K, Ali S, Imran M, Ghaffar MA \& Tamkeen A, (2018). Faunistic work on bumblebee (Hymenoptera: Apidae) of District Kharmang, Skardu, Pakistan. $J$ Biol Environ Sci 13(4): 141-146.

20. Khan H, Rafi MA, Baset A, Hussain A, Attaullah M \& Waris A (2018). Exploring of bumble bee fauna and its biogeographical affiliation in district Swat, Khyber Pakhtunkhwa, Pakistan. J Entomol Zool Stud 6(6): 1041-1048. 